\title{
SEBARAN KELIMPAHAN CUMI-CUMI DAN MUSIM PENANGKAPANNYA DI PERAIRAN SELATALAS
}

\author{
Sri Turni Hartati*), Indar Sri Wahyuni*), Wiwiet An Pralampita*), dan \\ Umi Chodriyah*)
}

\begin{abstract}
ABSTRAK
Penelitian tentang sebaran kelimpahan cumi-cumi dan musim penangkapannya telah dilakukan di perairan Selat Alas pada bulan Mei 1996 sampai bulan Maret 1998. Tujuan penelitian adalah untuk mengetahui sebaran kelimpahan cumi-cumi menurut ruang, waktu dan musim penangkapannya. Penelitian dilakukan dengan cara mengikuti kegiatan nelayan melakukan penangkapan dan pengamatan langsung hasil tangkapan nelayan di tempat pendaratan ikan. Alat tangkap yang digunakan adalah payang oras, kegiatan penangkapannya dilakukan selama satu malam (one-day fishing). Hasil penelitian menunjukkan bahwa pada musim peralihan 2 (September-November) cumi-cumi tersebar di perairan Pantai Lombok (10 daerah penangkapan) dengan indeks kelimpahan rata-rata 23,0 kg/trip. Selama musim Barat Laut (Desember-Februari) penyebaran cumi-cumi meluas sampai ke perairan Pantai Sumbawa (15 daerah penangkapan), dengan indeks kelimpahan rata-rata $40,3 \mathrm{~kg} / \mathrm{trip}$. Musim peralihan 1 yang berlangsung pada bulan Maret-Mei, daerah penyebaran lebih menyempit (12 daerah penangkapan) dengan indeks kelimpahan rata-rata 12,1 kg/trip. Musim Tenggara (Juni-Agustus) adalah akhir dari musim cumicumi dengan indeks kelimpahan relatif rendah $8,9 \mathrm{~kg} /$ trip dan daerah penyebaran hanya di lima daerah penangkapan utama. Pada musim cumi-cumi berlangsung dari bulan Oktober-Maret dan puncaknya pada bulan November, sedangkan masa paceklik terjadi bulan April-September.
\end{abstract}

\section{ABSTRACT: Distribution of squids resource abundance and their fishing season in the Alas Strait. By: Sri Turni Hartati, Indar Sri Wahyuni, Wiwiet An Pralampita, and Umi Chodriyah}

Study on the abundance distribution of squid and fishing season were conducted in the waters of Alas Strait from May 1996 to March 1998. The aim of activity was to obtain information the abundance distribution of squid in both spatial and temporal terms. The research was carried out by following fishermen's activities and by directly observing the catches in the landing place namely Tanjung Luar. The gear used by fisherman is seine net (payang oras) with one-night operation time (one-day fishing). In the second inter monsoon (September-November) squid was distributed only around Lombok beach (10 catch areas) where average of abundance index of about $23.0 \mathrm{~kg}$ /trip. During northwest season (December-February), the catch area of squid was extended until Sumbawa with average of index abundance about $40.3 \mathrm{~kg} / \mathrm{trip}$. During first inter monsoon (March-May) their distribution was rather narrow relatively, with average of abundance index was $12.1 \mathrm{~kg} / \mathrm{trip}$. Southwest season (June-August) was the end of squid season with average index of abundance was about $8.9 \mathrm{~kg} / \mathrm{trip}$ and the squids were distributed only in five catch areas. The squid catch season occurs in October-March, while the peak season is in November. The scarcity of squid was occurres in April until September.

KEYWOROS: squids, fishing saason, Alas Strait

\section{PENDAHULUAN}

Secara geografis perairan Indonesia yang terletak di kawasan tropis kaya akan berbagai sumber daya ikan. Salah satu sumber daya ikan yang bernilai ekonomis tinggi adalah cumi-cumi, karena selain rasanya enak, hampir seluruh bagian tubuhnya dapat dimakan juga bergizi tinggi. Kreuzer (1986) mengemukakan bahwa cumi-curni mengandung mineral fosfor, lisin, dan ornega tiga yang berperan dalam proses pembentukan tulang, pertumbuhan dan metabolisme tubuh.

Perdagangan dunia komoditas cumi-cumi berkembang dengan pesat dari tahun ke tahun. Data statistik dari FAO menyajikan bahwa hasil tangkapan total sefalopoda dunia pada tahun 1977 sebesar 1,22 juta ton meningkat menjadi 2,70 juta ton pada tahun 1992 (Ismail \& Pratiwi, 1996). Hasil tangkapan terbanyak berasal dari Jepang (29,5\%-35,5\%), yang didominasi oleh cumi-cumi yaitu sekitar $80 \%$.

- Peneliti pada Balai Penelitian Perikanan Laut, Muara Baru 
Sebagai spesies neritik cumi-cumi menyebar di seluruh perairan dekat pantai dan sekitar pulau-pulau. Hasil tangkapan dari perairan Indonesia selama periode tahun 1986-1995 berkisar antara 10.931 ton sampai 27.575 ton, dengan kenaikan rata-rata sekitar 16\% per tahun (Anonim, 1985). Cumi-cumi tersebar hampir di seluruh wilayah perairan Indonesia dan hanya di beberapa wilayah perairan saja yang konsentrasinya tinggi, di antaranya di perairan Selat Alas.

Hasil tangkapan cumi-cumi dari perairan Selat Alas dan Selat Sape (Nusa Tenggara Barat) menyumbang sekitar 15\% produksi cumi-cumi nasional (Marzuki et al., 1989). Alat tangkap utamanya adalah payang oras, yang dioperasikan pada malam hari dengan menggunakan lampu petromaks sebagai alat bantu penangkapan. Pusat pendaratan hasil tangkapan berada di Desa Tanjung Luar, Kabupaten Lombok Timur.

Tujuan dari penelitian adalah untuk mengetahui pola sebaran kelimpahan cumi-cumi menurut ruang, waktu dan musim penangkapannya di perairan Selat Alas. Diharapkan hasil penelitian dapat digunakan sebagai masukan dalam penyusunan kebijaksanaan pengelolaan dan pengembangan pemanfaatan cumicumi di Indonesia terutama di perairan Selat Alas.

\section{BAHAN DAN METODE}

Penelitian dilakukan di perairan Selat Alas, yang letaknya berbatasan dengan Pulau Lombok sebelah barat dan Pulau Sumbawa sebelah timur, sedangkan sebelah utara dibatasi oleh Laut Flores dan sebelah selatan dibatasi oleh Samudera Hindia. Perairan Selat Alas mempunyai luas perairan sekitar 56,89 mil persegi, dengan lebar mulut di bagian utara sekitar 11 mil dan di bagian selatan 19 mil. Penelitian dilakukan selama 2 tahun yaitu pada bulan Mei 1996 - Maret 1998

Pengumpulan data dilakukan dengan pengamatan langsung di lapangan meliputi pengamatan kondisi lingkungan oseanografi, pendugaan kelimpahan cumicumi, dan penelusuran data pada instansi terkait yang berhubungan dengan perikanan cumi-cumi

\section{Pengamatan Kondisi Lingkungan Oseanografi}

Parameter oseanografi yang diamati meliputi suhu, salinitas, oksigen terlarut, kandungan nitrat, kelimpahan fitoplankton dan zooplankton. Suhu diukur dengan menggunakan termometer balik, salinitas dengan salinometer, oksigen terlarut dengan titrasi Winkler, kandungan nitrat dengan spektrofotometer dan kelimpahan fitoplankton dan zooplankton diamati dengan menggunakan mikroskop. Stasiun pengamat- an ditentukan secara acak, yaitu di daerah penangkapan dan sekitarnya. Penentuan posisi dari stasiun pengamatan dilakukan dengan menggunakan GPS Pengamatan dilakukan sebanyak 4 kali, yaitu pada bulan Mei yang mewakili musim peralihan 1 (MaretMei), bulan Agustus mewakili musim tenggara (JuniAgustus), bulan Oktober mewakili musim peralihan 2 dan bulan Januari mewakili musim barat laut (Desember-Februari).

\section{Pendugaan Kelimpahan Cumi-cumi}

Pendugaan kelimpahan cumi-cumi dilakukan dengan mengikuti kegiatan nelayan melakukan operasional penangkapan cumi-cumi dan pengamatan langsung terhadap hasil tangkapan nelayan di tempat pendaratan ikan. Alat tangkap yang digunakan adalah payang oras dengan panjang tali ris atas $78,9 \mathrm{~m}$, panjang tali ris bawah 71,6 m dan alat bantu 3 buah lampu petromaks. Hasil tangkapan (bobot) per trip (dalam 1 malam melakukan kegiatan penangkapan) merupakan indeks kelimpahan yang dianggap sebanding dengan kelimpahan. Identifikasi jenis cumicumi dengan menggunakan acuan Roper et al.(1984)

\section{Data Statistik Perikanam}

Data statistik perikanan yang dikumpulkan berupa data hasil tangkapan cumi-cumi bulanan selama periode tahun 1985-1997. Data tersebut diperoleh dari Resor Perikanan Tanjung Luar, Kabupaten Lombok Timur

\section{Analisis Data}

\section{Pendugaan kelimpahan cumi-cumi}

Data kelimpahan cumi-cumi yang diperoleh dari mengikuti kegiatan nelayan dan pengamatan langsung hasil tangkapan nelayan di TPI dirata-ratakan untuk satu musim di suatu lokasi penangkapan (fishing ground). Pola sebaran kelimpahan cumi-cumi setiap musim disajikan pada suatu peta perairan.

\section{Musim penangkapan cumi-cumi}

Secara sederhana musim ikan dalam setiap tahun adalah produksi bulanan $\left(X_{i j}\right)$ yang lebih besar daripada produksi rata-rata bulanan dalam tahun tersebut $\left(X_{i}\right)$. Selama periode waktu tertentu dalam hal ini 1985-1997, maka metode analisisnya yang didasarkan pada produksi bulanan adalah sebagai berikut :

$$
\mathrm{X} . \mathrm{j}=\frac{1}{\mathrm{~h}} \sum_{i} X_{i j}=T \cdot \frac{j}{h}
$$

dengan: 
$X_{i j}=$ produksi bulanan pada bulan ke-j dan tahun ke

$\mathrm{X} . \mathrm{j}=$ produksi rata-rata bulanan dalam periode $\mathrm{h}$ tahun

$i=\operatorname{tahun}(i=1,2, \ldots h=13)$

$\mathrm{j}=\operatorname{bulan}(\mathrm{j}=1,2, \ldots n=12)$

$$
\mathrm{X}_{\mathrm{i}}=\frac{1}{\mathrm{n}_{\mathrm{i}}} \sum X_{i j}=\frac{T_{i}}{n_{i}}
$$

$\bar{X}=$ produksi rata-rata per bulan dalam tahun ke!

$$
\bar{X}=\frac{1}{n_{i}} \sum \sum X_{i j}=\frac{T}{n}
$$

dengan:

$n=S_{1} n=156(13 \times 12$ bulan $=156$ bulan $)$

$X=$ produksi rata-rata bulanan total

$T=S T . j=S T_{i}$

Musim cumi-cumi ditentukan dari nilai $X . j$ terhadap $X$, dengan $X . j>X$ dikatakan musim cumicumi, sedangkan $X . j<X$ adalah bukan musim cumicumi (Uktolseja, 1993).

\section{HASIL. DAN BAHASAN}

\section{Kekayaan Jenis Cumi-cumi}

Hasil pengamatan selama penelitian dan berdasarkan penelitian yang telah dilakukan oleh Ghoffar (1998), di perairan Selat Alas terdapat 7 jenis cumi-cumi dari suku Loliginidae, yaitu cumi-cumi jam ak Loligo duvauceli), tarusan (Loligo edulis), jarum (Uroteuthis bartschi), lamun (Sepioteuthis lessoniana), Loligo sibogae, Loligo chinensis dan Loligo beka. Empat jenis pertama merupakan jenis yang sering dijumpai selama penelitian dan didominasi oleh cumi-cumi jamak ( $80 \%$ ). Cumi-cumi jamak, tarusan dan jarum tertangkap dengan alat tangkap yang sama yaitu payang oras dan pada daerah tangkapan yang sama pula. Sedangkan cumi-cumi lamun tertangkap dengan pancing dan mempunyai daerah tangkapan yang berbeda dengan ketiga jenis cumi-cumi tersebut. Cumi-cumi lamun biasanya tertangkap di perairan Tanjung Cina sampai Kuta, yaitu pantai selatan Pulau Lombok yang berbatasan dengan Samudera Hindia

\section{Kondisi Lingkungan Oseanografi}

Pengamatan kondisi lingkungan oseanografi pada musim barat laut, tenggara dan kedua musim peralihan di antaranya disajikan pada Gambar 1

Suhu permukaan laut Selat Alas pada musim tenggara relatif lebih rendah daripada musim barat laut dan kedua musim peralihan di antaranya. Nilai ratam rata suhu pada musim tenggara (Juni-Agustus) sekitar $26^{\circ} \mathrm{C}$, sedangkan pada musim barat laut (DesemberFebruari) dan musim peralihan 2 (September-November) nilai rata-rata suhu sekitar $28^{\circ} \mathrm{C}$ dan pada musim peralihan 1 (Maret-Mei) nilai rata-rata suhunya sekitar $29^{\circ} \mathrm{C}$. Kondisi suhu perairan akan berpengaruh baik terhadap waktu pemijahan cumi-cumi maupun masa inkubasi sampai telur menetas. Pada umumnya cumicumi akan memijah dan telur akan cepat menetas pada saat suhu perairan relatif tinggi (Field, 1965; Roper et al., 1984). Hasil pengamatan tingkat kematangan gonad (TKG) cumi-cumi jamak yang dilakukan pada bulan Mei dan Juni, 57\% sampel dalam kondisi TKG V dan 19\% dalam kondisi TKG VI (sudah memijah). Keadaan tersebut menunjukkan bahwa ada dugaan puncak musim pemijahan cumi-cumi jamak berlangsung pada akhir musim peralihan yang suhunya relatif tinggi. Kaitannya dengan hasil tangkapan cumicumi adalah bahwa indeks kelimpahan cumi-cumi relatif rendah pada musim peralihan 1 dan musim tenggara, karena puncak musim pemijahan cumi-cumi yang diduga berlangsung pada musim peralihan 1 bermigrasi dalam kelompok yang besar ke dasar perairan berpasir pada kedalaman $30 \mathrm{~m}$ - 40 m untuk melakukan pemijahan (Roper et al., 1984). Payang oras sebagai alat tangkap utama cumi-cumi tidak akan mencapai keberadaan cumi-cumi di dasar perairan. Rendahnya indeks kelimpahan pada musim tenggara diduga karena cumi-cumi masih berukuran lebih kecil daripada ukuran mața jaring payang oras sebagai alat tangkap utama

Salinitas permukaan laut Selat Alas relatif tinggi baik pada musim barat laut, tenggara maupun pada musim peralihan di antaranya, yaitu berkisar antara 33 permil - 34 permil. Jenis cumi-cumi dari suku Loliginidae adalah penghuni demersal atau semi pelagik pada daerah pantai sampai kedalaman 400 $\mathrm{m}$. Cumi-cumi tersebut mempunyai toleransi salinitas yang cukup besar, dapat hidup baik pada salinitas rendah maupun tinggi (Roper et al.,1984). Dengan demikian kondisi salinitas perairan Selat Alas tidak berpengaruh terhadap keberadaan sumber daya cumicumi.

Konsentrasi oksigen terlarut di perairan Selat Alas baik pada musim barat laut, tenggara, dan kedua musim peralihan diantaranya cukup mendukung untuk kehidupan biota perairan, yaitu berkisar antara 3,7= 4,4 mL/L. Menurut baku mutu yang ditetapkan KLH (1988), batas minimum oksigen terlarut untuk kehidupan biota laut adalah $4 \mathrm{mg} / \mathrm{L}$

Konsentrasi nitrat tertinggi di perairan Selat Alas terjadi pada musim tenggara, dengan nilai rata-rata 2,68 $\mu \mathrm{g}$-at./L. Pada musim barat dan kedua musim peralihan di antaranya relatif lebih rendah, yaitu nilai rata-ratanya berkisar antara $0,76-1,27 \mu \mathrm{g}$-at./L. 

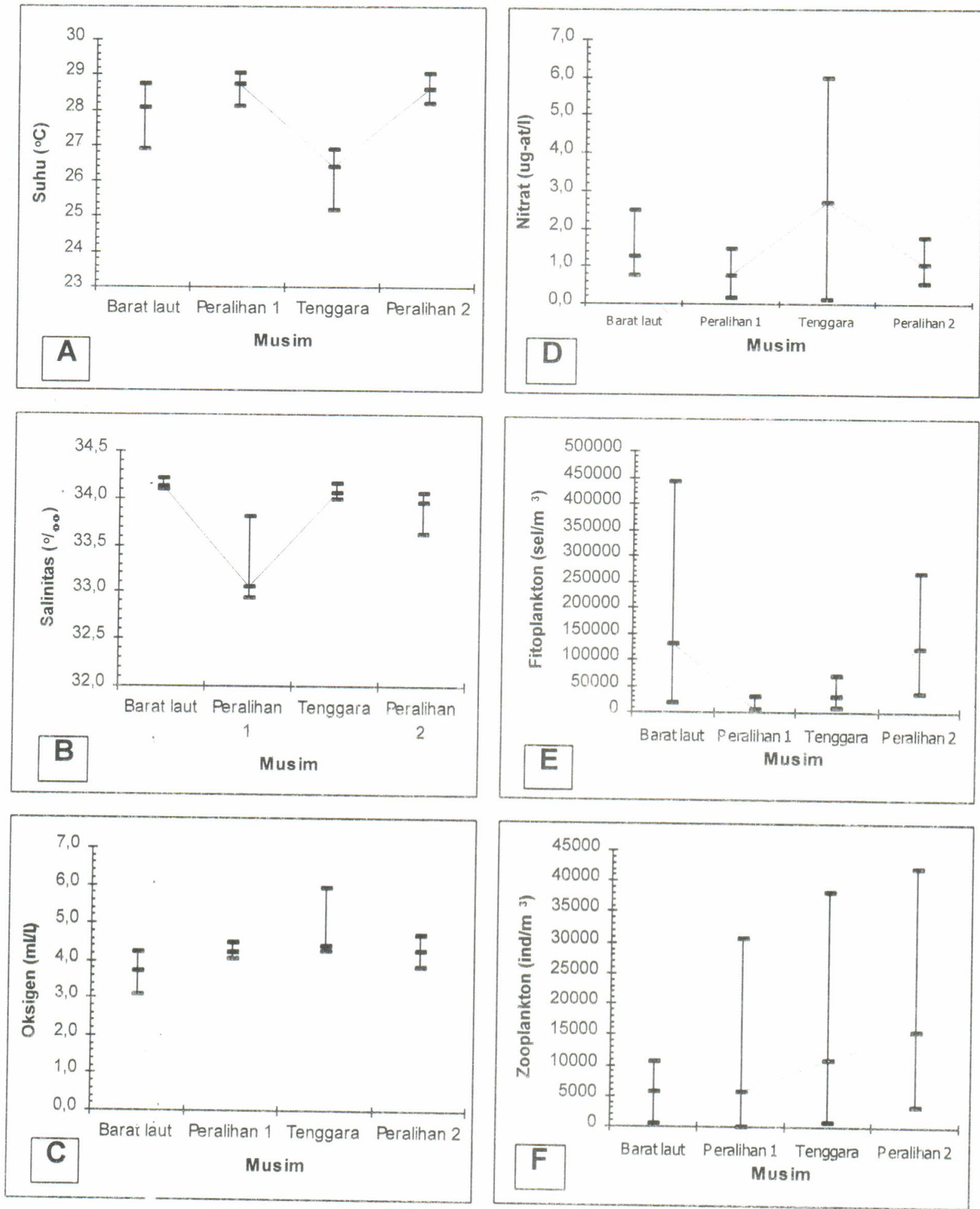

Gambar 1. Grafik nilai kisaran (max-nin) dan rerata parameter suhu (A), salinitas (B), oksigen $(C)$, nitrat (D), fitoplankton $(E)$ dan zooplankton ( $F$ ) di perairan Selat Alas pada musim

Figure 1 barat laut, peralihan satu, peralihan dua

Range and average of temperature, salinity, oxygen, nitrat, phytoplankton, zooplankton in Alas Strait on western, first inter musoon, and second inter musoon 
Secara oseanografis kondisi perairan Selat Alas dipengaruhi oleh perubahan-perubahan yang terjadi di perairan laut Flores dan Samudera Hindia. Selama musim tenggara terjadi pergerakan masa air yang cukup kuat dari selatan ke utara dan keadaan sebaliknya terjadi pada musim barat laut (Goi, 1982), sehingga dengan terjadinya umbalan (up welling) di perairan Samudera Hindia pada waktu musim tenggara menyebabkan tingginya konsentrasi nitrat di perairan Selat Alas.

Kelimpahan fitoplankton dan zooplankton dalam batasan tertentu dapat digunakan sebagai indikator kesuburan suatu perairan. Tingginya konsentrasi nitrat pada waktu musim tenggara akan membantu aktivitas fotosintesis fitoplankton dan akan berlanjut terhadap kelimpahan zooplankton sebagai pemakan fitoplankton. Zooplankton adalah makanan utama dari larva cumi-cumi dan larva ikan lainnya setelah persediaan kuning telur dari larva mulai habis. Hasil pengamatan memperlihatkan bahwa kelimpahan zooplankton relatif lebih tinggi pada waktu musim tenggara dan musim peralihan 2 . Tingginya zooplankton ini akan tepat (match) apabila pada saat yang sama berlangsung pula penetasan massal telur cumicumi.

Apabila dugaan bahwa puncak musim pemijahan cumi-cumi berlangsung pada bulan Mei dan Juni (akhir musim peralihan 1) itu benar, maka tingginya kelimpahan zooplankton pada musim tenggara (JuniAgustus) sangat tepat dengan keberadan larva cumicumi.

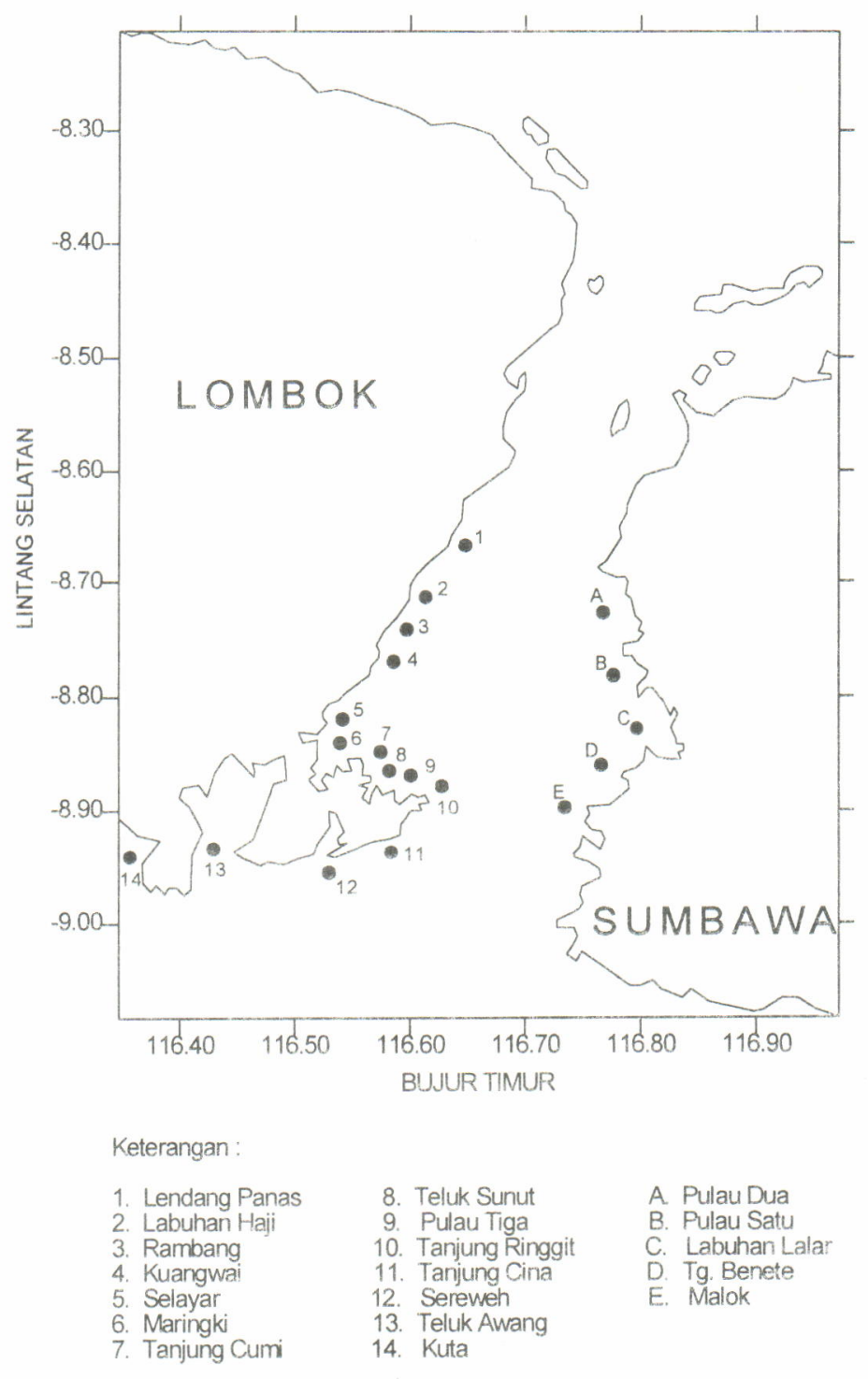

Gambar 2. Daerah penangkapan cumi-cumi di perairan Selat Alas

Figure 2. Fishing ground of squids at Alas Strait 


\section{Pola Sebaran Indeks Kelimpahan Cumi- cumi}

Kegiatan penangkapan cumi-cumi di perairan Selat Alas meliputi 19 daerah penangkapan (Gambar 2) Daerah penangkapan terdapat di sepanjang pantai Pulau Lombok dari Lendang Panas sampai Kuta dan sepanjang pantai Pulau Sumbawa dari Pulau Dua sampai Malok. Tiga daerah penangkapan utama dan potensial yaitu Tanjung Ringgit, Kuang Wai, dan Selayar, yang berada di pantai Pulau Lombok.
Musim peralihan 2 (September-November) diduga merupakan awal musim cumi-cumi. Cumi-cumi tersebar di 10 daerah penangkapan (Gambar 3D). Kelimpahan cumi-cumi berkisar antara 9,5-50,0 kg/ trip dengan nilai rata-rata $23,0 \mathrm{~kg} /$ trip. Pada musim barat laut (Desember-Februari) daerah penangkapan cumi-cumi relatif lebih menyebar dan kelimpahannya relatif lebih tinggi. Cumi-cumi tersebar di 15 daerah penangkapan (Gambar 3A). Kelimpahan cumi-cumi berkisar antara 10,0-100 kg/trip dengan nilai rata-rata 40,3 kg/trip. Musim peralihan 1 (Maret-Mei) kelimpahan cumi-cumi relatif lebih rendah dan daerah sebarannya
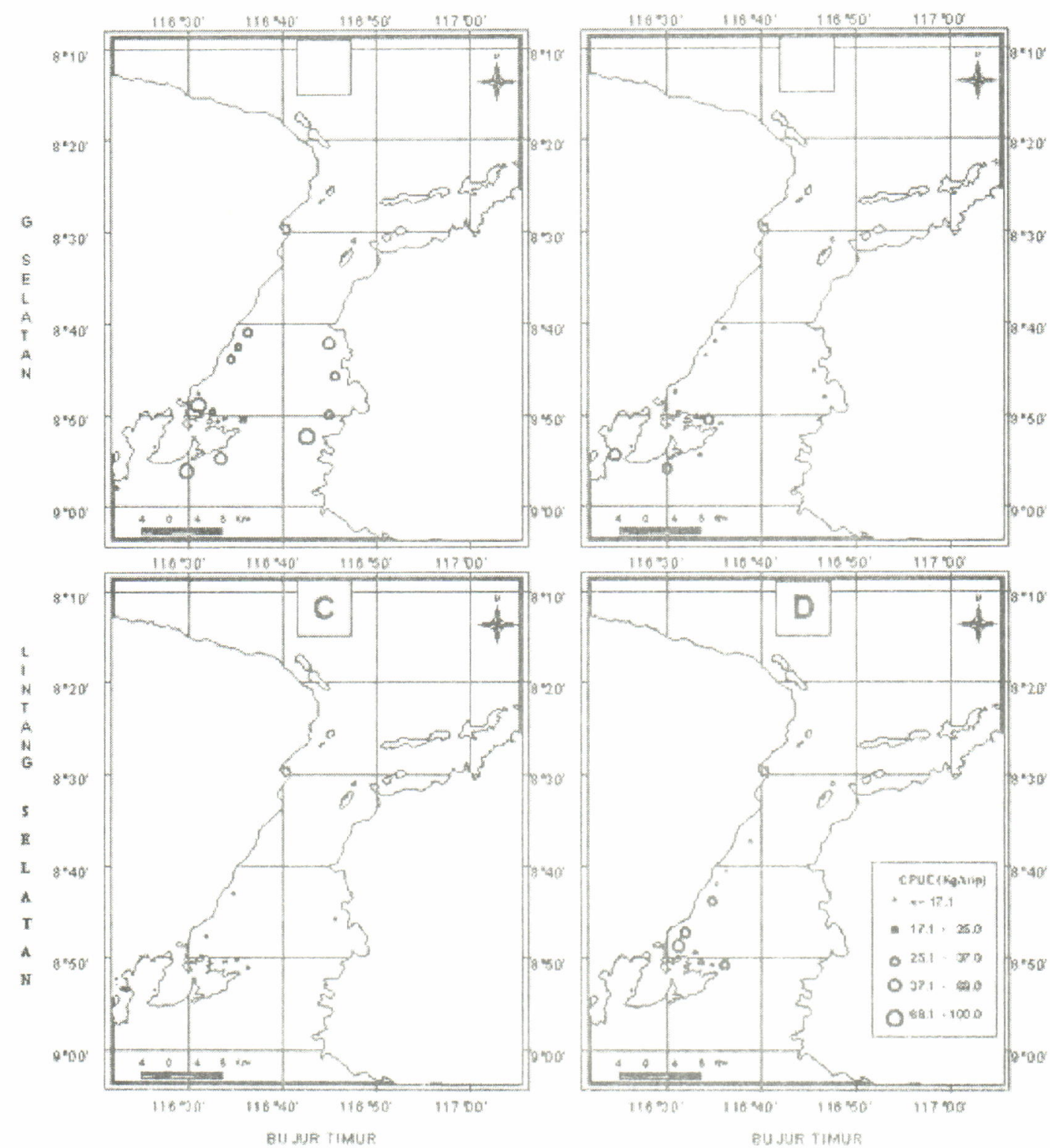

Gambar 3. Pola sebaran kelimpahan cumi-cumi ( $\mathrm{kg} / \mathrm{trip}$ ) di perairan Selat Alas pada musim barat laut (A), peralihan satu (B), tenggara (C), dan musim peralihan dua (D)

Figure 3. Distribution pattern of squid abundance ( $\mathrm{kg} / \mathrm{trip}$ ) in Alas Strait on western (A), first inter monsoon (B), southeast (C), and second inter monsoon (D) 
pun relatif lebih sempit. Cumi-cumi tersebar di 12 daerah penangkapan (Gambar 3B). Kelimpahannya berkisar antara 4,5-41,8 kg/trip dengan nilai rata-rata $12,1 \mathrm{~kg} /$ trip. Musim tenggara (Juni-Agustus) merupakan akhir musim cumi-cumi. Kelimpahannya sangat rendah berkisar antara 5,2-16,6 kg/trip, dengan nilai rata-rata $8,9 \mathrm{~kg} /$ trip dan hanya tersebar di 5 daerah penangkapan (Gambar 3C).

\section{Pola Musim Penangkapan Cumi-cumi}

Sifat musiman cumi-cumi ditunjukkan oleh hasil tangkapan cumi-cumi rata-rata bulanan dalam kurun waktu 13 tahun antara tahun 1985-1997. Berdasarkan Gambar 4 yang disajikan dapat dilihat bahwa musim cumi-cumi di perairan Selat Alas berlangsung dari bulan Oktober sampai dengan bulan Maret. Hal ini ditunjukkan dengan nilai indeks musim yang positif (di atas nilai nol) atau rata-rata hasil tangkapan bulan tersebut lebih tinggi daripada rata-rata bulanan total. Masa paceklik cumi-cumi terjadi pada bulan April sampai dengan September, ditunjukkan dengan nilai indeks musim yang negatif atau rata-rata hasil tangkapan bulan tersebut lebih rendah daripada ratarata bulanan total. Puncak musim penangkapan dengan nilai indeks musim 1,97 berlangsung pada bulan November. Rata-rata hasil tangkapan pada bulan November selama 13 tahun sebesar 123,83 ton; sedangkan rata-rata hasil tangkapan bulanan total hanya sebesar 41,7 ton

\section{KESIMPULAN}

(1) Awal musim cumi-cumi berlangsung pada musim peralihan 2 (September-November), dengan indeks kelimpahan $23,0 \mathrm{~kg} /$ trip dan hanya tersebar di perairan pantai Lombok. Musim Barat Laut (Desember-Februari) daerah penyebaran relatif lebih luas, yaitu sampai perairan pantai Sumbawa dengan indeks kelimpahan relatif lebih tinggi yaitu $40,3 \mathrm{~kg} / \mathrm{trip}$. Musim peralihan satu (Maret-Mei) indeks kelimpahan mulai menurun yaitu $12,1 \mathrm{~kg} /$ trip dan daerah penyebaran pun relatif lebih sempit. Musim Tenggara (Juni-Agustus) merupakan akhir musim cumi-cumi dengan indeks kelimpahan 8,9 $\mathrm{kg} /$ trip dan penyebarannya hanya di daerah tangkapan utama (perairan Tanjung Ringgit sampai Kuang Wai).

(2) Musim penangkapan cumi-cumi berlangsung dari bulan Oktober-Maret, sedangkan masa paceklik bulan April-September.

\section{DAFTAR PUSTAKA}

Anonimous. 1995. Statistik Perikanan Indonesia. Ditjen Perikanan, Departemen Pertanian. Jakarta. 102 pp.

Fiel, G.W. 1965. The Structure, development, food relation reproduction and life history of the squid loligo opalescens Perry. The Resources Agency. Department of Fish and Game. Fish Bulletin. 131. State of California. $108 \mathrm{pp}$.

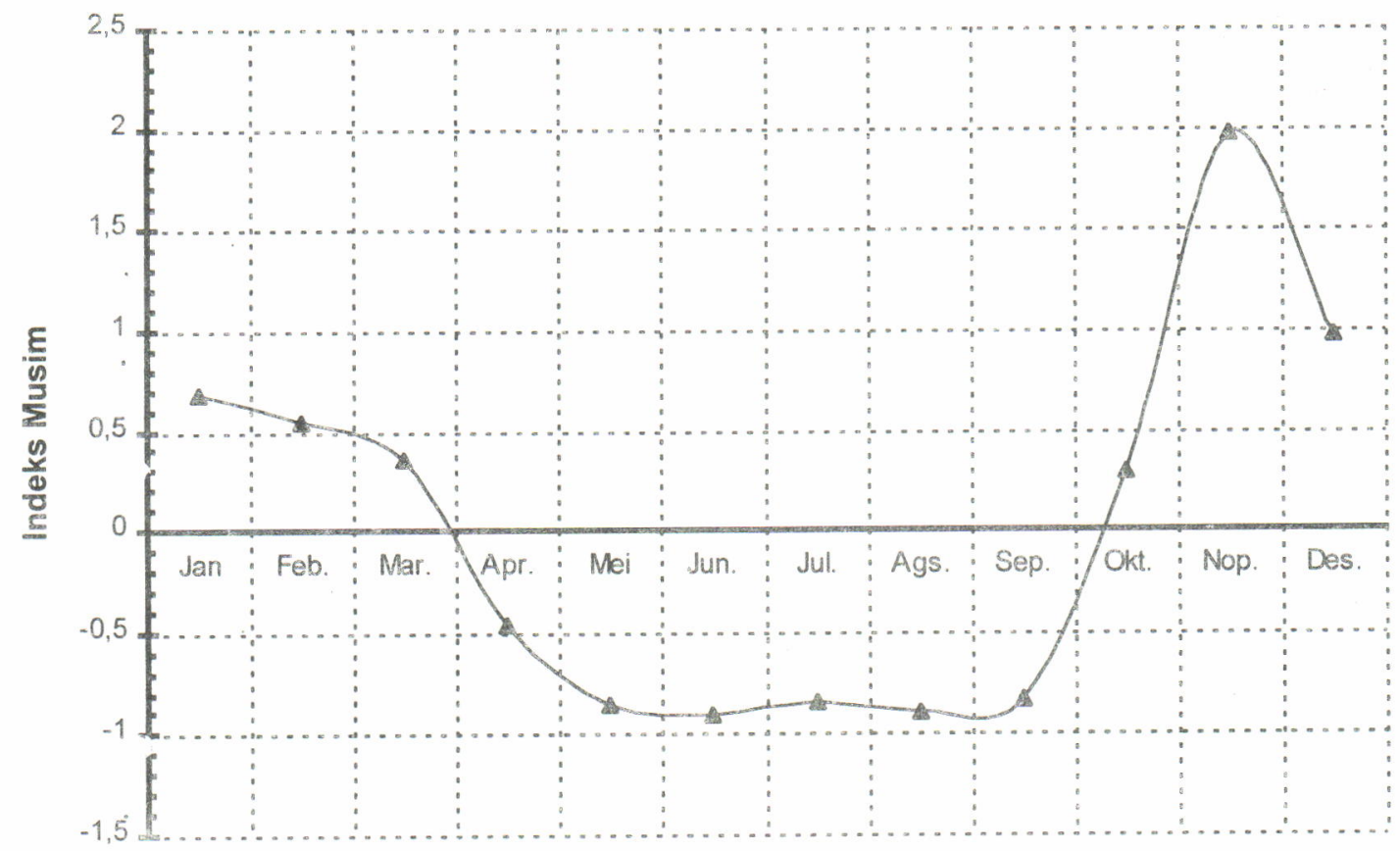

Bulan

Gambar 4. Pola musim penangkapan cumi-cumi di perairan Selat Alas tahun 1985-1987 Figure 4. Pattern of squids catch season in Alas Strait, 1985-1987 
ment of Fish and Game. Fish Bulletin. 131. State of California. $108 \mathrm{pp}$.

Ghofar, A. 1998. Perkembangan perikanan pantai di Selat Alas, Nusa Tenggara Barat, 1960-1967. Konferensi Nasional 1. Pengelolaan Sumberdaya Pesisir dan Lautan di Indonesia.

Goi. 1982. Sumber perikanan demersal di Samudera Hindia. Evaluasi Hasil Survei IOP. Ditjen Perikanan. Departemen Pertanian. Jakarta

Ismail. W dan E. Pratiwi. 1996. Status dan prospek perikanan cumi-cumi dan sejenisnya (Cephalopoda) di Indonesia. Warta Penelitian Perikanan Indonesia. II(2):7-13.
KLH. 1988. Keputusan Menteri Negara Kependudukan dan Lingkungan Hidup No: Kep.02/MenKLH/I/1988. Tentang Pedoman Penetapan Baku Mutu Lingkungan. Sekretariat Menteri Negara KLH. 57 pp. Kreuzer, R. 1986. Squid-Sea Food Extra Ordinary. IndoFish. 66/86:29-32.

Marzuki, S., T. Hariati, dan R. Rustam. 1989. Sumberdaya cumi-cumi (Loliginedae steenstrup, 1861) di Perairan Selat Alas, Nusa Tenggara Barat. J. Penelitian Perikanan Laut. 52:95-105.

Roper, C.F.E., M.J. Sweeney, and Nauen. 1984. Cepalopods of the world. An annotated and illustrated catalogue of species of interest to fisheries. FAO Species Cataloque III(125): 277 pp. 